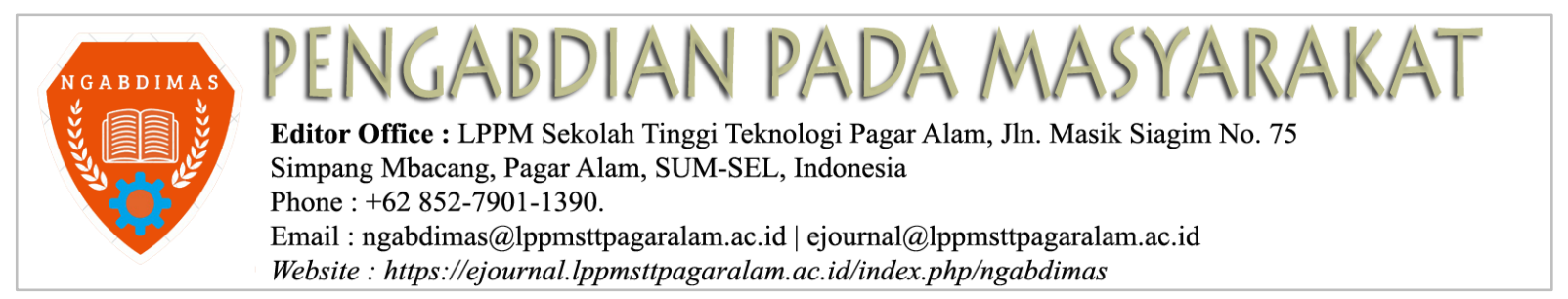

\title{
PENDAMPINGAN PENGELOLAAN/PENYULUHAN SAMPAH (3R) KAB. MANNA
}

\author{
Fameira Dhiniati \\ Program Studi Teknik Sipil; Sekolah Tinggi Teknologi Pagaralam (STTP) \\ Jl. M. Siagim No. 75. Karang Dalo, Dempo Tengah, Kota Pagar Alam \\ Telp/Fax: (0730) 621916 \\ e-mail: dhiniati@gmail.com
}

\begin{abstract}
Abstrak
Sampah merupakan sesuatu atau sisa-sisa dari proses yang dilakukan manusia terhadap berbagai hal dalam menghasilkan suatu produk tertentu, sisa-sisa ini terkadang di buat atau di posisikan sebagai sesuatu yang kadang sangat tidak berharga, bahkan di identikan sebagai sesuatu yang sangat menjijikan untuk di kelola sebagai sesuatu yang memiliki nilai lebih, keberadaan sampah yang sangat nyata terkadang menjadi sesuatu masalah yang sangat rumit dan sangat kompleks. Masalah sampah ini pada saat sampah tersebut sedikit terkadang seolah tidak tampak memiliki masalah, tetapi pada saat sampah tersebut bervolume sangat banyak maka masalah mulai di rasakan oleh penghuni di sekitarnya, misalnya kejadian yang luar biasa dari keberadaan sampah adalah pernah terjadi di Bandung, Bandung yang sering di sebut kota kembang pada saat pemerintah tak sanggup mengelola sampah dengan baik sebutannya menjadi Bandung Kota Sampah, lain lagi di Jakarta phenomena banjir yang setiap ada hujan hampir di pastikan terjadi banjir, salah satu penyebabnya adalah akibat sampah walau sebenarnya hal lain lebih dominan seperti akibat penggundulan di hulu sungai yang ada di Bogor. Penomena sampah ini memang sangat luar biasa, walau pun sangat banyak merugikan dan kesan yang melekat sangat menjijikan ini sebagai bukti dari kedisiplinan, dan kearifan masyarakat dalam berprilaku dalam kehidupannya bermasyarakat, jika tiap individu berprilaku sesuai norma dan tatanan kehidupan yang umum sebenarnya tak akan pernah terjadi permasalahan sampah ini. Tentu yang harus menjadi perhatian terutama bagi penyuluh adalah menyadarkan masyarakat untuk berpola dan tingkah hidup sesuai aturan yang sesuai aturan. Penomena dari sampah yang lain adalah ternyata di balik kesan dan imej yang buruk, penyebab banjir, banyak lalat, kotor, dan menjijikan ternyata terdapat sisi positif bagi beberapa orang yang kreatif, bagi orang-orang tertentu yang kreatif terkadang sampah ini bisa di jadikan sesuatu yang unik, menarik bahkan memiliki nilai jual yang cukup tinggi, misalnya di beberapa daerah di Jawa terdapat pengrajin olahan sampah atau limbah rumah tangga yang tak terlalu bermanfaat, misalnya kantong-kantong plastic bekas makanan dan sabun di bersihkan sehingga menjadi Tas atau tempan menyimpan sesuatu. Ini sampah menjadi sesuatu yang berharga sehingga memiliki nilai jual, bahkan sampah seperti sampah-sampah kayu bisa menjadi kerajinan tertentu.
\end{abstract}

Kata kunci-Pengabdian, STTP, Guru, Blog, Pembelajaran, Materi.

\section{PENDAHULUAN}

Sampah merupakan sesuatu yang terkadang sangat sulit untuk di tangani, sampah bila di lihat dari keberadaanya pada saat berjumlah sedikit seolah tidak berpengaruh terhadap apa pun, sampah baru terasa mempengaruhi sisi kehidupan manusia setelah sampah yang ada bervolume sangat besar, bahkan pengaruh sampah ini bisa sampai berakibat merugikan yang luar biasa, sampah yang terkadang tidak berpengaruh dan tidak berarti lagi bagi kehidupan juga ternyata ada yang berpengaruh baik.

Sampah yang berakibat merugikan diakibatkan oleh sampah yang tidak dikelola dengan baik, tidak di tempatkan pada tempatnya yang sesuai, volumenya tidak diatur sedemikian baik, sehingga sampah yang seolah tak berpengaruh menjadi sesuatu yang mematikan bagi kehidupan. 
Sampah ternyata dapat berpengaruh baik terhadap kehidupan seseorang, terutama dalam hal ini bagi sesorang bisa membaca dan melihat/menangkap peluang dari keberadaan sampah/limbah (sampah) yang ada, bahkan sampah bagi mereka ini bisa mendatangkan penghasilan (uang) sehingga menjadi kesejahteraan bagi orang bertipe seperti ini, berbagai masalah inilah sehingga masyarakat perlu di damping dan di beri penyuluhan sehingga masyarakat tidak memandang sampah dari hal negative saja, selain itu agar masyarakat menjadi masyarakat yang peduli dan disiplin serta arif menghadapi permasalah sampah ini.

\section{METODE}

Maka urutan pelaksanaan dari pengabdian yang dilakukan adalah mengikuti aturan sebagai berikut, terdiri dari:

\subsection{Metode}

Teknik yang digunakan dalam penyampaian materi pelatihan adalah workshop, dengan menggunakan alat bantu berupa laptop, LCD.

2.2 Materi Pendahuluan

Sampah adalah buangan yang dihasilkan dari suatu proses produksi baik industri maupun domestik (rumah tangga). Sementara didalam UU No 18 Tahun 2008 tentang Pengelolaan Sampah, disebutkan sampah adalah sisa kegiatan sehari hari manusia atau proses alam yang berbentuk padat atau semi padat berupa zat organik atau anorganik bersifat dapat terurai atau tidak dapat terurai yang dianggap sudah tidak berguna lagi dan dibuang kelingkungan. Sampah berasal dari beberapa tempat, yakni :

1. Sampah dari pemukiman penduduk pada suatu pemukiman biasanya sampah dihasilkan oleh suatu keluarga yang tinggal disuatu bangunan atau asrama. Jenis sampah yang dihasilkan biasanya cendrung organik, seperti sisa makanan atau sampah yang bersifat basah, kering, abu plastik dan lainnya.

2. Sampah dari tempat-tempat umum dan perdagangan tempat tempat umum adalah tempat yang dimungkinkan banyaknya orang berkumpul dan melakukan kegiatan. Tempat-tempat tersebut mempunyai potensi yang cukup besar dalam memproduksi sampah termasuk tempat perdagangan seperti pertokoan dan pasar. Jenis sampah yang dihasilkan umumnya berupa sisa-sisa makanan,sayuran busuk, sampah kering, abu, plastik, kertas, dan kaleng-kaleng serta sampah lainnya.

Berbagai macam sampah yang telah disebutkan diatas hanyalah sebagian kecil saja dari sumbersumber sampah yang dapat ditemukan dalam kehidupan sehari-hari. Hal ini menunjukkan bahwa kehidupan manusia tidak akan pernah lepas dari sampah. Terutama penumpukan sampah yang terjadi di tempat-tempat umum seperti di pasar-pasar.

\section{HASIL DAN PEMBAHASAN}

3.1 Hasil

Kegiatan pendampingan pengelolaan (manajemen) sampah telah terlaksana dengan baik di ikuti oleh masyarakat Kelurahan Manna Kota, Kabupaten Manna Provinsi Bengkulu dengan peserta 15 Orang Bertempat di Kelurahan.

\subsection{Pembahasan}

Jenis-jenis sampah jenis sampah yang ada di sekitar kita cukup beraneka ragam, ada yang berupa sampah rumah tangga, sampah industri, sampah pasar, sampah rumah sakit, sampah pertanian, sampah perkebunan, sampah peternakan, sampah ninstitusi / kantor / sekolah, dan sebagainya. Berdasarkan asalnya, sampah padat dapat digolongkan menjadi 2 (dua) yaitu sebagai berikut :

1. Sampah organic, adalah sampah yang dihasilkan dari bahan-bahan hayati yang dapat didegradasi oleh mikroba atau bersifat biodegradable. Sampah ini dengan mudah dapat diuraikan melalui proses alami. Sampah rumah tangga sebagian besar merupakan bahan organik. Termasuk sampah organik, misalnya sampah dari dapur, sisa-sisa makanan, 
pembungkus (selain kertas, karet dan plastik), tepung, sayuran, kulit buah, daun dan ranting. Selain itu, pasar tradisional juga banyak menyumbangkan sampah organik seperti sampah sayuran, buah-buahan dan lain-lain.

2. Sampah Anorganik adalah sampah yang dihasilkan dari bahan-bahan non hayati, baik berupa produk sintetik maupun hasil proses teknologi pengolahan bahan tambang. Sampah anorganik dibedakan menjadi : sampah logam dan produk-produk olahannya, sampah plastik, sampah kertas, sampah kaca dan keramik, sampah detergen. Sebagian besar anorganik tidak dapat diurai oleh alam/ mikroorganisme secara keseluruhan (unbiodegradable). Sementara, sebagian lainnya hanya dapat diuraikan dalam waktu yang lama. Sampah jenis ini pada tingkat rumah tangga misalnya botol plastik, botol gelas, tas plastik, dan kaleng, (Gelbert dkk, 1996).

Berdasarkan wujud atau bentuknya dikenal tiga macam sampah atau limbah yaitu : limbah cair, limbah padat, dan limbah gas. Contoh limbah cair yaitu air cucian, air sabun, minyak goreng sisa, dll. Contoh limbah padat yaitu bungkus snack, ban bekas, botol air minum, dll. Contoh limbah gas yaitu karbon dioksida $\left(\mathrm{CO}_{2}\right)$, karbon monoksida $(\mathrm{CO}), \mathrm{HCl}, \mathrm{NO}_{2}, \mathrm{SO}_{2}$ dll. Dampak negatif sampah-sampah padat yang bertumpuk banyak tidak dapat teruraikan dalam waktu yang lama akan mencemarkan tanah. Yang dikategorikan sampah disini adalah bahan yang tidak dipakai lagi ( refuse) karena telah diambil bagian-bagian utamanya dengan pengolahan menjadi bagian yang tidak disukai dan secara ekonomi tidak ada harganya. Menurut Gelbert dkk (1996) ada tiga dampak sampah terhadap manusia dan lingkungan yaitu:

a. Dampak terhadap kesehatan

Lokasi dan pengelolaan sampah yang kurang memadai (pembuangan sampah yang tidak terkontrol) merupakan tempat yang cocok bagi beberapa organisme dan menarik bagi berbagai binatang seperti, lalat dan anjing yang dapat menjangkitkan penyakit. Potensi bahaya kesehatan yang dapat ditimbulkan adalah sebagai berikut :

- Penyakit diare, kolera, tifus menyebar dengan cepat karena virus yang berasal dari sampah dengan pengelolaan tidak tepat dapat bercampur air minum. Penyakit demam berdarah (haemorhagic fever) dapat juga meningkat dengan cepat di daerah yang pengelolaan sampahnya kurang memadai.

- Penyakit jamur dapat juga menyebar (misalnya jamur kulit).

- Penyakit yang dapat menyebar melalui rantai makanan. Salahsatu contohnya adalah suatu penyakit yang dijangkitkan oleh cacing pita(taenia). Cacing ini sebelumnya masuk kedalam pencernakan binatang ternak melalui makanannya yang berupa sisa makanan/sampah.

b. Dampak terhadap lingkungan

Cairan rembesan sampah yang masuk kedalam drainase atau sungai akan mencemari air. Berbagai organisme termasuk ikan dapat mati sehingga beberapa spesien akan lenyap, hal ini mengakibatkan berubahnya ekosistem perairan biologis. Penguraian sampah yang di buang kedalam air akan menghasilkan asam organik dan gas cair organik, seperti metana. Selain berbau kurang sedap, gas ini pada konsentrasi tinggi dapat meledak.

c. Dampak Terhadap Keadaan Sosial dan Ekonomi

Dampak-dampak tersebut adalah sebagai berikut :

- Pengelolaan sampah yang tidak memadai menyebabkan rendahnya tingkat kesehatan masyarakat. Hal penting disini adalah meningkatnya pembiayaan (untuk mengobati kerumah sakit).

- Infrastruktur lain dapat juga dipengaruhi oleh pengelolaan sampah yang tidak memadai, seperti tingginya biaya yang diperlukan untuk pengolahan air. Jika sarana penampungan sampah kurang atau tidak efisien, orang akan cenderung membuang sampahnya dijalan. Hal ini mengakibatkan jalan perlu lebih sering dibersihkan dan diperbaiki.

Pengelolaan Sampah Dengan Konsep 3R

Menurut Departemen Pekerjaan Umum Kota Semarang (2008), pengertian pengelolaan sampah 3R secara umum adalah upaya pengurangan pembuangan sampah, melalui program menggunakan kembali (Reuse), mengurangi (Reduce), dan mendaur ulang (Recycle). 
1. Reuse (menggunakan kembali) yaitu penggunaan kembali sampah secara langsung,baik untuk fungsi yang sama maupun fungsi lain.

2. Reduce (mengurangi) yaitu mengurangi segala sesuatu yang menyebabkan timbulnya sampah.

3. Recycle (mendaur ulang) yaitu memanfaatkan kembali sampah setelah mengalami proses pengolahan.

Mengurangi sampah dari sumber timbulan, di perlukan upaya untukmengurangi sampah mulai dari hulu sampai hilir, upaya-upaya yang dapat dilakukan dalam mengurangi sampah dari sumber sampah (darihulu) adalah menerapkan prinsip 3R.

Teknik Pengolahan Sampah

Sampah adalah sebagian dari sesuatu yang tidak dipakai, tidak disenangi atau sesuatu yang harus dibuang, yang umumnya berasal dari kegiatan yang dilakukan oleh manusia (termasuk kegiatan industri), tetapi bukan biologis (karena human waste tidak termasuk didalamnya) dan umumnya bersifat padat.

Sumber sampah bisa bermacam-macam, diantaranya adalah : dari rumah tangga, pasar, warung, kantor, bangunan umum, industri, dan jalan. Berdasarkan komposisi kimianya, maka sampah dibagi menjadi sampah organik dan sampah anorganik. Penelitian mengenai sampah padat di Indonesia menunjukkan bahwa 80\% merupakan sampah organik, dan diperkirakan $78 \%$ dari sampah tersebut dapat digunakan kembali. Pengelolaan sampah adalah semua kegiatan yang dilakukan dalam menangani sampah sejak ditimbulkan sampai dengan pembuangan akhir. Secara garis besar, kegiatan di dalam pengelolaan sampah meliputi pengendalian timbulan sampah, pengumpulan sampah, transfer dan transport, pengolahan dan pembuangan akhir.

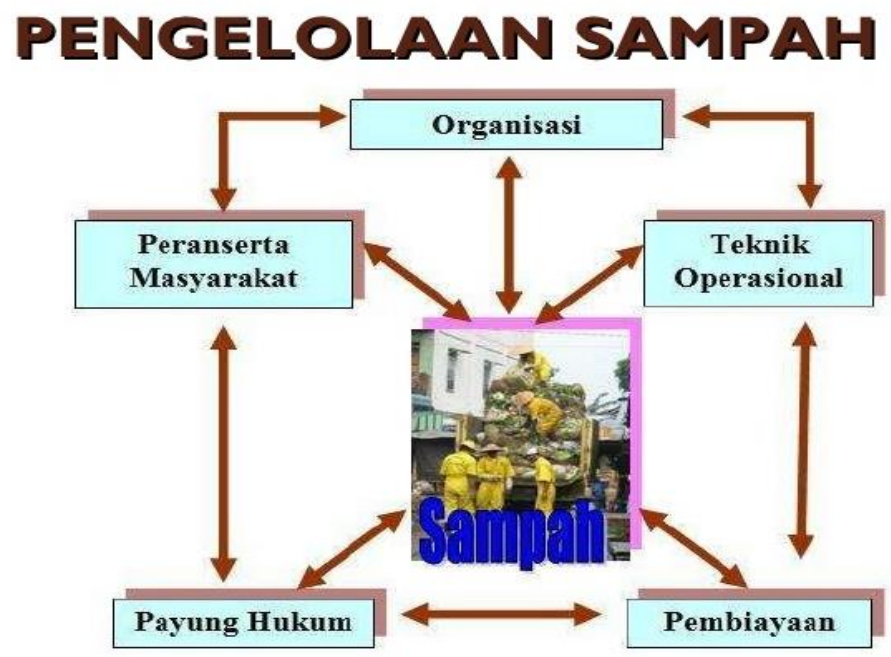

Gambar 1. Pengelolaan Sampah 


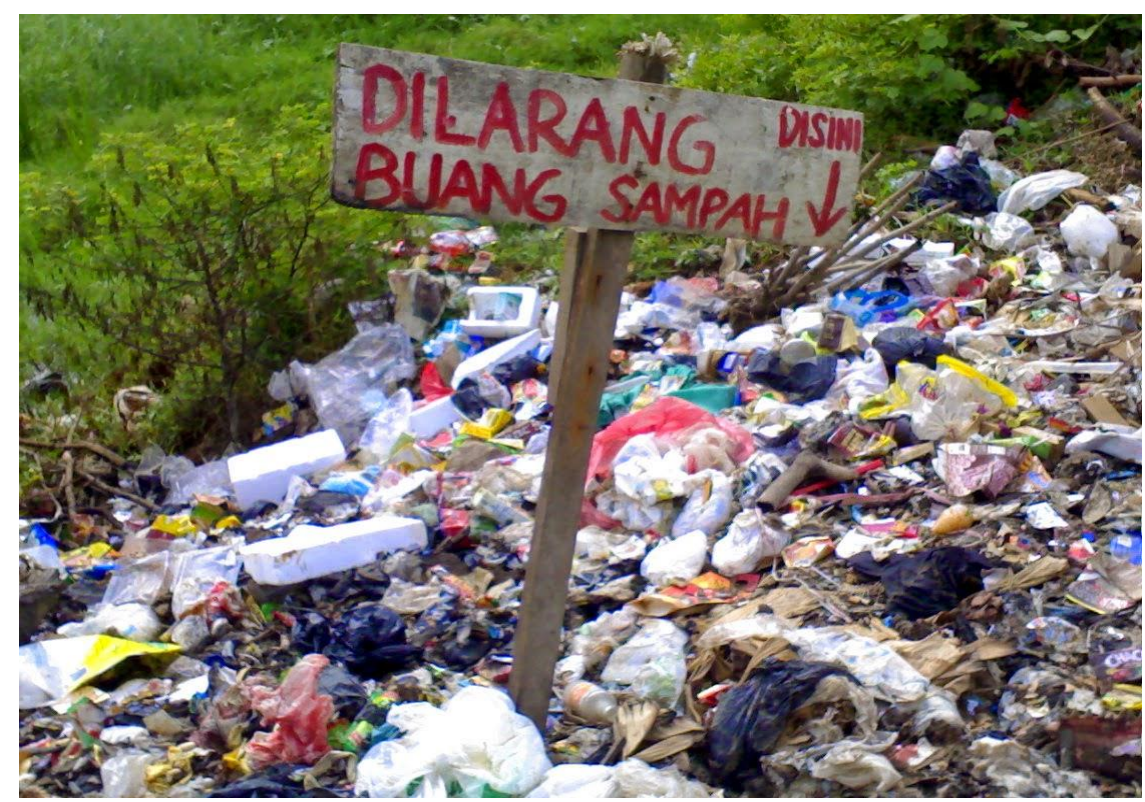

Gambar 2. Sampah dibuang sembarang

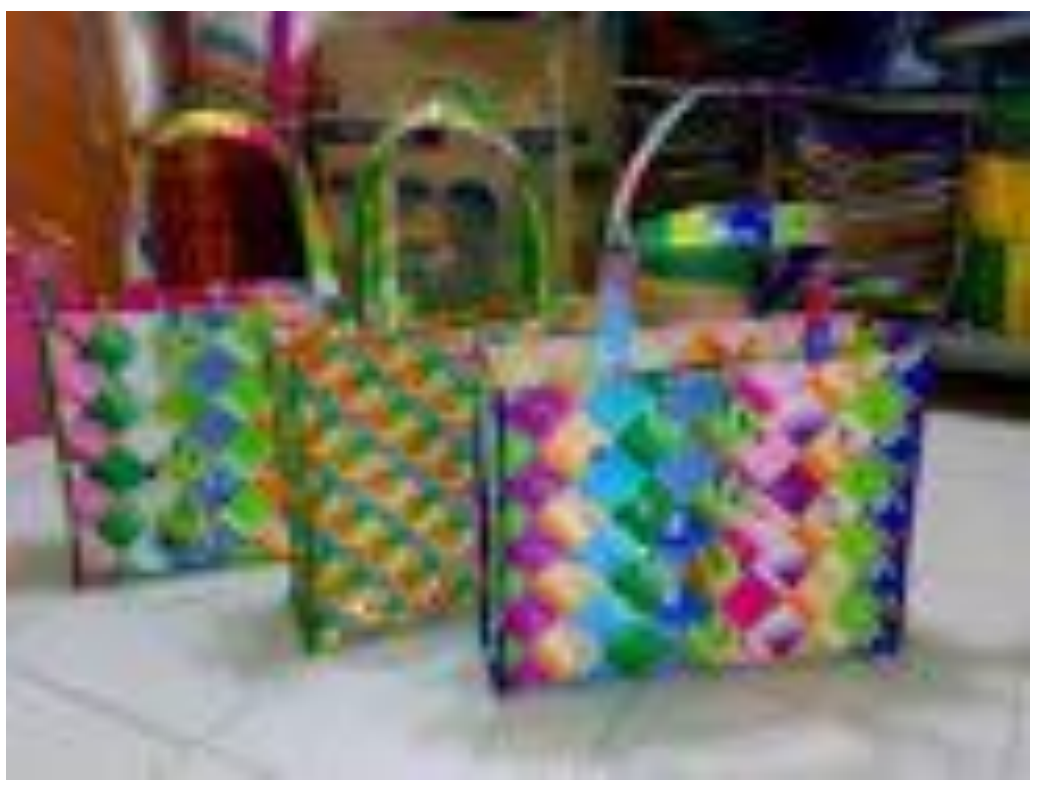

Gambar 3. Sampah Plastik

\section{KESIMPULAN}

Berdasarkan hasil pelaksanaan kegiatan ini bahwa pengelolaan sampah menjadi hal yang sangat penting untuk dikaji mengingat sampah merupakan sesuatu hal yang sangat harus di perhatikan pada saat bervolume besar, tetapi pada saat volume sedikit pun harus di kelola dengan baik.

\section{SARAN}

Berdasarkan metode dan pembahasan sehingga diperoleh saran bagi pelaksana pengabdian pada masa yang akan datang, sebagai berikut:

1. Kelola dan manajemen dengan baik sampah pada saat sampah memiliki volume terbatas, pada saat bervolume cukup banyak harus lebih disiplin mengelola, perhatikan kapasitas dan tempat sehingga tidak terjadi overload di tempat penampungan. 
2. Perhatikan peluang dari barang bekas/limbah/sampah bukan hanya di buang begitu saja apa yang mungkin di perbuat, sehingga dari sampah dapat memiliki nilai tambah yang justru meningkatkan tarap kehidupan.

\section{UCAPAN TERIMA KASIH}

Penulis mengucapkan terima kasih kepada LPPM divisi Pengabdian.

\section{DAFTAR PUSTAKA}

[1] Hartono, Didiek. 2005. Alternatif Pemenuhan Air Bersih Oleh PDAM di Kota Semarang.

[2] Kondoatie, Robert J dan Sjarief, Roestam. 2005. Pengelolaan Sumber Daya Air Terpadu. Yogyakarta: Penerbit ANDI.

[3] Linsley, K Ray.dkk.1991.Teknik Sumber Daya Air Jilid 1. Jakarta. Penerbit: Erlangga.

[4] Mungkasa, Osmar. 2006. Pembangunan Air Minum dan Pembangunan. Jurnal Percik, Edisi Oktober 2006, hal.18-20.

[5]__ 2008. Akses Air Bersih untuk Masyarakat Miskin. Jurnal Percik, Edisi Oktober 2008, hal.42.

[6] Mulia, Ricki M. 2005. Kesehatan Lingkungan. Yogyakarta: Penerbit Graha Ilmu.

[7] Maryono. 2007. Menilai Aksesibilitas Air Minum (Studi kasus: Aksesibilitas AirBersih Bagi Masyarakat Miskin di Kota Semarang.

[8] Parahita, Diah. 2009. Penyediaan Air Bersih Oleh Komunitas. Avalaible at: www.ciptakarya.pu.go.id. Diakses tanggal 10 November 2009. 